\title{
P.T. Насыров
}

Актюбинский региональный университет имени К. Жубанова, Казахстан, г. Актобе, e-mail: nassyrov1997@gmail.com

\section{РАСПАА СССР КАК ЗАКОНОМЕРНЫЙ РЕЗУАЬТАТ ПОАИТИКИ ПЕРЕСТРОЙКИ}

\begin{abstract}
Сложившаяся к середине 80-х гг. ситуация в Советском Союзе требовала преобразований в экономике и общественно-политической сфере страны. Значительнее всего влияние на развитие страны оказывал кризис власти. ПришеАший к власти в марте 1985 года М.С. Горбачёв отлича^ся не только возрастом от своих преАшественников, но и оценкой установившегося положения в государстве. В апреле 1985 года Горбачёв объявил о переходе к курсу ускорения социальноэкономического развития, который впоследствии трансформировался в программу перестройки, затронувшей и политическую систему страны. Тем не менее, замыслы Горбачёва о плавном преобразовании структуры Советского государства наяву столкнулись с резким обострением напряжённости в обществе по причине значительно ухудшившегося уровня жизни и проявления первых межнациональных конфмиктов.

В 1988-1989 гг. стало ясно то, что реформы усугубили положение СССР и стали своеобразным трамплином Аля старта дезинтеграционных процессов в 1990 году. Внешняя политика государства также была значительно изменена, согласно «новому политическому мышлению», в результате чего позиции СССР на международной арене были критически ослаблены. Все данные обстоятельства привели к распаАу Союза в 1991 году. Многие последствия этого события Ао сих пор оказывают ощутимое влияние на развитие 15 независимых государств

Кмючевые слова: перестройка, политика гласности, Пленум ЦК КПСС, ускорение, новое политическое мышление, М.С. Горбачёв, Б.Н. Ельцин, А.Н. Яковлев, Р. Рейган, холодная война, разоружение, распаА СССР.
\end{abstract}

\author{
R.T. Nassyrov \\ K. Zhubanov Aktobe Regional University, Kazakhstan, Aktobe, \\ e-mail: nassyrov1997@gmail.com \\ The disintegration of the USSR is a natural result \\ of the policy of restructuring
}

By the mid-1980s, the situation in the Soviet Union required a change of the economy and the socio-political sphere of the country. The crisis of power had the greatest impact on the country's development. When M.S. Gorbachev came to power in March 1985, not only was age significantly different from his predecessors but also an assessment of the established situation in the State. In April 1985, Gorbachev announced to accelerate economic and social development, which was transformed into a programme of restructuring that, also affected the country's political system. However, Gorbachev's ideas for a smooth transformation of the structure of the Soviet state actually faced with a sharp increase in social tensions due to a significantly deteriorating standard of living and manifestations of the first inter-ethnic conflicts. In 1988-1989, it became clear that the reforms had aggravated the situation of the USSR and became the springboard for the start of disintegration processes in 1990. The State's foreign policy has been changed significantly, according to «new political thinking», as a result, the positions of the Soviet Union in the international arena was critically weakened. All these circumstances have led to the dissolution of the Union in 1991. Many of the consequences of this event still have a tangible impact for the development of 15 independent states.

Key words: perestroika, publicity policy, Plenum of CC CPSU, acceleration, new political thinking, M.S. Gorbachev, B.N. Eltsin, A.N. Yakovlev, R. Reagan, Cold War, demilitarization, fall of the USSR.

\section{P.Т. Насыров}

Қ. Жұбанов атындағы Ақтөбе өңірлік университеті, Қазақстан, Ақтөбе қ. e-mail: nassyrov1997@gmail.com

\section{КСРО-ның ыдырауы - қайта құру саясатының заңды нәтижесі}

80-жылдардың ортасына қарай Кеңес Одағындағы қалыптасқан жағдай елдің экономикасы мен қоғамдық-саяси саласында қайта құруларды талап етті. Биліктің дағдарысы елдің дамуына едәуір әсер етті. 1985 жылы наурызда билікке келген М.С. Горбачев, жас ерекшелігі бойынша 
өзінен бұрынғылардан ғана емес, сонымен қатар мемлекеттегі қалыптасқан жағдайды бағалауымен де айтарлықтай ерекшеленді. 1985 жылы сәуірде Горбачев әлеуметтік-экономикалық, дамуды жеделдету курсына көшу туралы жариялады, ол кейіннен елдің саяси жүйесіне де әсер ететін қайта құру бағдарламасына айна^ды.

Соған қарамастан Горбачевтің Кеңес мемлекетінің құрылымын біртіндеп өзгертуге бағытталған жоспарлары шын мәнінде өмір деңгейінің айтарлықтай нашарлауына және алғашқы этносаралық қақтығыстардың көрінуіне байланысты қоғамдағы шиеленістің күрт өршуіне тап болды. 1988-1989 жж. реформалардың КСРО-дағы жағдайды шиеленістіргені және 1990 жылы ыдырау процестерін бастауға арналған трамплинге айналғаны айқын болды. Мемлекеттің сыртқы саясаты да "жаңа саяси ойлауға» сәйкес едәуір өзгеріске ұшырады, нәтижесінде КСРО-ның халықаралық аренадағы позициясы өте әлсіреді. Осы жағдайлардың барлығы 1991 жылы ОАақтың күйреуіне әкелді. Бұл оқиғаның көптеген салдары әлі күнге дейін 15 тәуелсіз мемлекеттің дамуына әсер етеді.

Түйін сөздер: «қайта құру» саясаты, жариялылық саясаты, КОКП ОК пленумы, жеделдету, жаңа саяси ойлау, М.С. Горбачёв, Б.Н. Ельцин, А.Н. Яковлев, Р. Рейган, қырғи қабақ соғысы, қарусыздану, КСРО-ның ыдырауы.

\section{Введение}

В настоящее время сложившееся положение на постсоветском пространстве - наличие межгосударственных территориальных споров, рост межэтнических противоречий, переходящих в острые конфликты, стопорят дальнейшее развитие многих государств, создают значимую напряжённость и недоверие друг к другу. Актуальность данного исследования состоит в том, что споры о различных аспектах распада Советского Союза даже спустя три десятилетия будоражат умы практически всех групп населения государств, в прошлом составляющих одно целое. Одной из причин начала крупнейшего дезинтеграционного процесса в новейшей истории, как известно, стали экономические и политические кризисные моменты, возникшие в СССР к середине 80-х годов. Однако, также существуют и другие версии и концепции возникновения предпосылок, приведших к краху страны Советов: от подрывной деятельности спецслужб США и стран НАТО, а также действовавшего по их плану М. С. Горбачёва, проводившего намеренно убийственную политику по отношению к своей стране, до того, что советский государственный строй рухнул сам по себе, а экономика и система хозяйствования были изначально мертворождёнными. Соответственно, целью данного исследования являются поиск и анализ основных факторов, повлиявших на распад Советского Союза.

\section{Материалы и методы}

Источниковой базой исследования послужили труды крупных советских, российских и западных экономистов, историков, социо- логов. Советский экономист, один из авторов экономической реформы периода перестройки Л.И. Абалкин в своём труде (Абалкин, 2007) привёл мнение о ключевых предпосылках возникновения кризисных явлений в советском народном хозяйстве в начале 70 -х годов. М.А. Рахматуллин и М.Е. Морозова провели колоссальную работу по изучению российской истории и довольно подробно исследовали советский период истории (Рахматуллин, Морозова, 2018). Авторами были опубликованы сведения о многих негативных тенденциях, сложившихся в советском обществе в результате процесса перестройки. Тем не менее, придерживаясь позиции нейтральности исследователя, авторы индифферентно оценили, как личность М.С. Горбачёва, так и его деятельность. Труды зарубежных историков по изучению периода перестройки посвящены либо советской дипломатии, либо проблемам по правам человека и возникновению межнациональных конфликтов. Д. Хоскинг развёрнуто повествует о росте межэтнического напряжения в советском обществе во второй половине 80-х годов (Хоскинг, 2001).

Бывший государственный секретарь США в период с 1973 по 1977 год Г. Киссинджер, впоследствии участвовавший в организации встреч Горбачёва и Рейгана, передал важные сведения о саммитах в Женеве и Рейкьявике, мнениях американских политиков о советском руководителе (Киссинджер, 2018). Мемуары самой «центральной фигуры» в последнем периоде истории СССР - М.С. Горбачёва являются достаточно ценным источником для нашего научного исследования, так как воспоминания, мысли и размышления последнего советского руководителя позволяют проанализировать основные мотивы деятельности и принятия решений главы госу- 
дарства (Горбачёв, 2014). Особый интерес представляют мнения и позиции различных зарубежных исследователей. В частности, американским историком У. Таубманом высказаны предположения о намеренном умысле действий первого и последнего президента СССР по дестабилизации положения Советского Союза (Таубман, 2018). Профессор университета в Принстоне С. Коткин в своём труде исследовал советскую историю периода с 70-90-е гг. и изучил множественные аспекты событий тех лет (Коткин, 2018). Французский исследователь Н. Верт, являясь крупным советологом, дал свою оценку деятельности Горбачёва и его «команды», провёл анализ многих факторов, приведших к ослаблению СССР (Верт, 1992).

Российский исследователь-китаевед В.А. Глушаков в своём исследовании по истории КНР провёл сравнительный анализ по сходству и отличию реформ в Китае, начатых в 70-е годы и советских преобразований второй половины 80-х гг. (Глушаков, 2019).

Методологическую основу исследования формировали следующие принципы научноисторического познания: историзм, объективность, системность и конкретность, а также применяемый в исторических исследованиях ценностный подход. В комплексе, они предполагают всеобъемлющее, беспристрастное рассмотрение тех или иных исторических событий, учёт целого ряда факторов, оказавших влияние на деятельность исторической личности М.С. Горбачёва.

\section{Результаты и обсуждения}

В середину 80-х годов СССР вошёл в довольно неопределенном положении. С одной стороны, страна усиливала свой экономический потенциал - вторая экономика в мире после США, укреплялась обороноспособность, расширялись социальные гарантии, а авторитет Советского Союза признавался безусловно всеми государствами. Но именно в это время как во внутренней, так и во внешней политике проявляются многие кризисные моменты.

К 1984 году преобладание в промышленности группы «А»- производство средств производства составило $75 \%$, а производство предметов потребления $-25 \%$, что являлось причиной дефицита ряда товаров. Увеличивались закупки зерна за границей. Усиливалась нефтезависимость страны, которая во второй половине 80-х гг. станет катализатором экономического кри- зиса в СССР. Во внешней политике также возникло немало острых проблем. Затягивалось решение «афганского вопроса»; антикоммунистические настроения в ПНР усилились после запрета профсоюза «Солидарность»; экономические проблемы в других странах социалистического лагеря становились следствием постепенного разочарования не только в идеях плановой экономики, но и в вопросе целесообразности существования Совета экономической взаимопомощи и Организации Варшавского договора (Абалкин, 2007: 326).

Рассматривая тему экономического коллапса Советского Союза и находясь в поиске «корней» тех или иных процессов и явлений, приходится отходить всё более к ранним периодам истории СССР. Ещё в годы правления Н.С. Хрущёва серьёзно меняются установки и социально-экономические цели политики партии, что в немалой степени предопределяет дальнейший вектор развития народного хозяйства. В первую очередь, это - изменение в идеологическом секторе, что было отражено в Третьей программе КПСС, принятой на XXII съезде партии 31 октября 1961 года. Н.С. Хрущёв авантюрно, в свойственной ему манере заявил, что за ближайшие 20 лет уровень доходов советских граждан вырастет в 3 раза, каждая семья получит новую благоустроенную квартиру, коммунальные услуги и проезд на общественном транспорте станут бесплатными, будет улучшена жизнь сельских тружеников. Официально данные планы были оформлены в программе КПСС, где также утверждалось о необходимости обеспечения в СССР лучшего уровня жизни, чем в развитых капиталистических государствах. Данный ход в политике партии произошёл достаточно обоснованно. Поколение фронтовиков, которое застало первые мероприятия Советской власти, трудности жизни в 1930-е годы, ужасы Великой Отечественной войны и восстанавливало страну после неё, попросту хотело сытой и спокойной жизни как своему поколению, так и своим потомкам (Верт, 1992: 234).

Хрущёвская «оттепель» помимо внутренних преобразований привела к изменениям и во внешней политике. Во второй половине 50-х гг. Советский Союз действительно отличался достаточно миролюбивой и открытой к диалогу внешней политикой. В 1958 г. было заключено соглашение с США о сотрудничестве в области культуры и науки. 24 июля 1959 г. в Москве в парке «Сокольники» была проведена Американская национальная выставка «Промышленная 
продукция США». На открытии мероприятия присутствовали вице-президент США Ричард Никсон и Никита Хрущев. Именно там прошли знаменитые «кухонные дебаты», получившие свое название за то, что диалоги через переводчиков между Хрущевым и Никсоном проходили в выставочной модели пригородного американского дома. Советские граждане получили возможность увидеть рекламу жизни в капиталистическом обществе. Именно тогда Хрущёвым озвучена ленинская догма: «Догнать и перегнать!», которая стала командой для обеспечения роста производства продуктов питания и промышленных товаров народного потребления. Что делалось, зачастую, любым путём и методом. Да, конечно, коммунизм сопряжён с ростом производства и максимальным удовлетворением потребностей общества и каждого человека в отдельности. Но потребление не является самоцелью или центральным элементом идеологии, потому что коммунизм, в первую очередь, конечно, очень обобщённо, но всё же представляет собой общественную собственность на средства производства, глобальное планирование и распределение, максимальная демократизация общества, преодоление отчуждения личности, новая культура и система межличностных отношений и т.д. Ставя во главу угла сугубо потребление, советское руководство способствовало укоренению и развитию мещанства, которое стало в итоге одним из факторов политического краха CCCP (Kissinger, 1994: 292).

То есть тот факт, что проблем, тревожных звонков и сигналов, деструктивных тенденций в советском народном хозяйстве в середине 80 -х гг. хватало, трудно отрицать. Но всё же нельзя считать её обреченной и неспособной на устойчивое развитие. Научная и техническая база были на довольно высоком уровне и смело конкурировала с капиталистической. Возможностей решить острые вопросы в экономике и дать импульс её развитию было немало. Нельзя не учитывать фактор перемен и в политическом поле страны. К 1987 году в СССР партийная номенклатура разделилась на 3 группы: консерваторы во главе с секретарём ЦК по организационнопартийной работе Е.К. Лигачёвым выступали за сохранение плановой экономики и отрицали возможность перехода к другим видам ведения народного хозяйства; противниками консерваторов являлись так называемые демократы, лидерами которых являлись заведующий отделом пропаганды ЦК КПСС А.Н. Яковлев и первый секретарь Московского городского комитета партии Б.Н. Ельцин, склонявшие руководство к началу рыночных преобразований. И третья группа - нейтрально настроенные генеральный секретарь М.С. Горбачёв и председатель Совета Министров Н.И. Рыжков, выступающие за последовательные преобразования. Причём демократы в своих выступлениях и речах открыто не призывали к полной реставрации буржуазно-капиталистических отношений. Все намерения затушёвывались цитатами из трудов В.И. Ленина, отсылками к НЭП, обвинениями в адрес «старой гвардии» в отходе от идей коммунизма, заявлениями о необходимости борьбы с партократией, представителями которой «демократы» и являлись. Спустя буквально 4 года, как Ельцин, уже будучи президентом Российской Федерации, в своём выступлении в Конгрессе США с радостью скажет об окончательной смерти коммунизма - самый настоящий курьёз во всей своей сути (Рахматуллин, Морозова, 2018: 1036).

В рамках политики ускорения социальноэкономического развития страны, объявленной Горбачёвым на апрельском Пленуме 1985 года, 19 августа 1986 года принято Постановление ЦК КПСС «О мерах по совершенствованию управления внешнеэкономическими связями». По нему министерствам и крупным предприятиям разрешалось вести торговлю на мировом рынке, хотя она и контролировалась министерством внешней торговли, Внешэкономбанком, всё же действие данного документа стало подрывать целостность государственной монополии в экспорте и задавало курс будущим экономическим реформам - к 1989 году все предприятия и производственные кооперативы получили право ведения торговли на внешнем рынке. К слову, такого Советское государство не позволяло себе даже в годы Новой экономической политики. Закон «Об индивидуальной трудовой деятельности» от 19 ноября 1986 года легализовал мелкое частное предпринимательство в сфере кустарно-ремесленных промыслов, бытового обслуживания населения и т.д. К 1990 году в ИТД было задействовано около 675 тыс. человек. Предприимчивые граждане, зачастую «совершенно случайно» являющиеся родственниками руководителей предприятий, используя ресурсы государства, абсолютно свободно развивали собственное производство. Регулирование цен на продукцию ИТД отсутствовало, что дало возможность за короткий срок на основе огромной разницы между государственными и спекулятивными ценами получить значительную прибыль. В свою очередь, концентрация крупных денежных сумм 
в руках отдельных предпринимателей усиливала товарно-денежный дисбаланс в советской экономике (Корниенко, 2019: 115).

30 июня 1987 года принят Закон СССР «О государственном предприятии». Согласно ему предприятие выполняет работы и заказы в соответствии с планом и договорами на основе полного хозрасчёта, самофинансирования, самоуправления, что предполагало сочетание централизованного руководства и самостоятельности. Забавно, что, добавив в «котёл» советской экономики щепотку с горкой анархо-синдикализма, руководство страны поспособствовало развитию капиталистических отношений. Теперь государство спускало лишь контрольные цифры производства, а предприятие могло производить больше, а товар самостоятельно реализовывать по рыночной цене. Если официально предполагалось усиление власти трудовых коллективов и каждого трудящегося по отдельности, то наяву всё взяли под контроль не обычные рабочие, у которых отсутствовали культура управления и необходимые для этого знания, да и желание управлять, а предприимчивые директора и руководители, которые не только реализовывали в продажу продукцию, произведённую сверх плана, но и снабжали спекулянтов материалом и сырьём. Более того, в условиях относительной экономической самостоятельности усложнился налоговый контроль - поступления в бюджет сокращались: в 1980 году каждое предприятие выплачивало около 60\% прибыли, то в 1990 году $-45 \%$. Однако, увеличившуюся оставшуюся прибыль руководители предприятий не отправляли на модернизацию и обновление материально-технической базы, что при условии увеличенного производства попросту изнашивало оборудование. Деньги распределялись среди управления и рабочих, что опять-таки усилило проблему дефицита и необеспеченности советского рубля. За годы «перестройки» денежные доходы увеличились на $52 \%$, а излишек денег к 1990 г. Госбанк оценивал в 47,5 млрд. руб. (Дробышевская, Мау, 2011: 148).

Абсурдом является крайне двойственная позиция руководства страны, которая наносила серьёзный ущерб народному хозяйству. С одной стороны, предприятия были отправлены в «свободное плавание», оставляя значительную часть прибыли у себя. С другой стороны, государство продолжало их снабжать сырьём, дотациями, например предприятия сельского хозяйства в 1989-1990 гг. субсидировались на 55\%. И если бы все данные действия были просто до- садными ошибками и глупостями, то ещё в 1987 году реформа была остановлена и изменена. Но трансформации только набирали скорость, и 26 мая 1988 года принят Закон «О кооперации в СССР». Им было санкционировано существование частного предпринимательства в потребительском секторе народного хозяйства. Отнюдь, кооператоры не стали создавать инновационные проекты и развивать креативную деятельность. Основой успешных кооперативов стала банальная спекуляция. 4/5 объектов кооперации функционировали при каком-либо государственном предприятии, приобретали выпущенную на нём продукцию по строго фиксированной цене, и спокойно перепродавали на рынке. Так, большинство кооперативов паразитировали на государственной промышленности, используя сложившуюся разницу в ценах. Именно кооперация дала возможность получению первой крупной прибыли будущим миллионерам и олигархам в постсоветских странах. Примечательно, что новый советский класс общества вызревал и под эгидой ВЛКСМ. В 1987 году «под крылом» комсомола были созданы Центры научно-технического творчества молодёжи, в которых неофициально занимались спекуляцией, фарцовкой, нелегальной скупкой иностранной валюты (Гайдар, 2020: 285).

В 1990 году началось преобразование целых министерств промышленности в концерны Министерство газовой промышленности СССР преобразовано в «Газпром»; Министерство тяжёлого машиностроения в «Тяжэнергомаш». Параллельно происходило разделение банковской системы Советского Союза на отдельные банки, а Госснаб на торговые дома и биржи. Шла целенаправленная работа по дезинтеграции, разбалансировке экономики страны, созданию таких условий, при которых плановые механизмы просто перестали адекватно функционировать. СМИ обвиняли в ухудшившимся положении людей саму плановую систему народного хозяйства, что давало возможность продолжать дальнейшее разрушение экономики (Глушаков, 2019: 302).

Не считаю то, что общественно-политические преобразования были случайно начаты одновременно с экономической реформой. Политика гласности, результатом которой стала бесконтрольная, практически анархическая либерализация средств массовой информации, смягчение цензуры в культуре отвлекали на себя всё внимание советских граждан от крупного передела народного хозяйства и его грабежа. 
Да, действительно, в советском обществе практически полностью отсутствовала какаялибо оппозиционность, не считая небольшого движения диссидентов. Конституция СССР 1977 года, а именно её 6 статья юридически закрепила идею о том, что «КПСС является руководящей и направляющей силой советского общества». Руководство страны официально постановило о том, что появление какой-либо иной политической силы в Советском Союзе попросту невозможно. Государство всячески контролировало деятельность средств массовой информации, цензурировало и влияло на развитие искусства и культуры. О многих насущных проблемах в экономике, социальной сфере, межнациональных отношениях, которые к середине 80-х годов ещё более обострились в прессе не сообщалось. Обсуждение острых политических вопросов происходило «на кухнях», то есть дома, в узком семейном кругу, либо в дружеских посиделках. Выборы в Советы, начиная от низовых - сельских и поселковых, и заканчивая высшим - Верховным Советом СССР были безальтернативными. Формально существовали беспартийные кандидаты, выставляемые различными общественными организациями, но, как правило, их позиции по отношению к политике КПСС не были оппозиционными (Хоскинг, 2001: 339).

События 1986 и 1987 годов предрешили судьбу СССР, так как последующие действия конца 80-х и начала 90-х гг. являются результатом действий, осуществлённых именно за эти два года. В 1986 году были начаты крупномасштабные общественно-политические преобразования. XXVII съезд КПСС (25 февраля -6 марта) стал отправной точкой в старте открытой критики Горбачёвым прежнего руководства. «Застоем» были прозваны как экономические, так и политические действия Брежнева, Андропова и Черненко. На съезде «дебютировал» Б.Н. Ельцин, вошедший в состав Политбюро партии буквально за неделю до его начала. Борис Николаевич активно поддержал действия Михаила Сергеевича и заявил о необходимости борьбы с привилегированной частью партийной номенклатуры. 6 марта 1986 года «архитектор перестройки» - Яковлев вошёл в состав ЦК КПСС и был назначен секретарем ЦК по идеологии, культуре и информации. Неофициально началось постепенное ослабление цензуры и контроля за деятелями литературы и искусства. С 25 сентября было прекращено глушение радиостанций «Би-би-си» и «Голос Америки» Комитетом Государственной Безопасности. Начиная с 1946 года, то есть с самого начала «холодной войны», спецслужбами США, Великобритании и ФРГ на территорию СССР передавались передачи, новости, мнения различных аналитиков, «свободная от советского влияния» информация. На самом же деле, объективность в большинстве своём отсутствовала как в советских СМИ, так и в западных. По данным ЦРУ США, в обход глушителей, слушателями данных радиоволн в день становилось около 35-40 миллионов человек (Коткин, 2018: 176).

1987 год - этап перехода к более решительным действиям Горбачёва и его сторонников. Спустя 70 лет после победы Революции, в СССР произошли события, по характеру схожие с Октябрём 1917 года. Страна стала изменяться, и причём очень быстро. 27-28 января состоялся Пленум ЦК КПСС, на котором были озвучены планы руководства страны, которые в последующем значительно изменят жизнь всего народа. Взамен политики ускорения социальноэкономического развития официальным курсом государства объявлена «перестройка», которая помимо реформирования экономики теперь затрагивала и общественно-политическую сферу, в том числе советскую избирательную систему, создавая в ней альтернативность и прозрачность. Заседание транслировалось Центральным Телевидением и отличалось от всех предыдущих Пленумов свободной очередью для выступающих, без соблюдения какого-либо ранжирования. На советского человека в столь короткое время в один момент обрушились немыслимые до этого изменения, которые были неизвестными ему, и чем-то пугающими. Публикации запрещённых до этого литературных произведений Булгакова, Пастернака и т.д., освещение в фильмах актуальных проблем - наркомания, подростковая преступность, создание аналитических программ на телевидении, в которых шло открытое обсуждение исторического прошлого - целесообразность Октябрьской революции, деятельность В.И. Ленина и И.В. Сталина, авантюризм Хрущёва и «застой» Брежнева. Словом, советское информационное пространство второй половины $80-\mathrm{x}$ гг. можно назвать одним из самых свободных и демократических в истории постсоветских государств (Taubman, 2018: 595).

Перемены произошли также и в международной политике СССР. Начиная с 1986 года Горбачёв начал проводить более уступчивый и направленный на улучшение отношений с Западом внешнеполитический курс. Руководство США тщательно прощупывало все личные каче- 
ства М.С. Горбачёва и его окружения. Они были твёрдо уверены в том, что генеральному секретарю ЦК КПСС более важна его положительная оценка со стороны Запада, чем довольство внутри страны, и поэтому он будет готов идти на односторонние уступки по многим вопросам. В мае по настоянию Москвы на пленуме Народнодемократической партии Афганистана генеральным секретарём был выбран Мохаммад Наджибулла, объявивший о начале политического решения внутреннего конфликта в республике. В июле 1986 года Горбачёв заявил о том, что СССР в ближайшее время выведет из Афганистана 6 полков своих вооружённых сил - 6955 человек, однако определённых сроков не назвал. Для ускорения принятия решения Москвой, с конца сентября США дали разрешение моджахедам массово использовать «Стингеры», было сбито 2 советских вертолёта (Ратьковский, Ходяков: 2001: 261).

22 августа в США был арестован и обвинён в шпионаже сотрудник посольства СССР Г. Захаров. В ответ, с тем же обвинением 3 сентября в Москве задержан журналист из США Н. Данилов. 10 сентября в Вашингтоне заявили о высылке 80 советских дипломатов по причине их «непозволительной деятельности» - что подразумевалось под этим, государственный секретарь США Дж. Шульц так и не смог объяснить. СССР же в свою очередь ответил запретом советским гражданам наниматься на работу в американские посольства и консульства. Тем самым дипломатическому корпусу США пришлось самостоятельно себя обслуживать, что вносило определённые трудности в их деятельность. 15 сентября советский руководитель предложил провести очередные переговоры со своим американским коллегой для решения дипломатического конфликта, а для сглаживания «обострившихся углов» и без того обострённых и напряжённых отношений между двумя странами Горбачёв объявил о дате начала вывода части войск из Афганистана. Ответ Рейгана и его администрации был положительным. 11-12 октября 1986 года в Рейкьявике - середина расстояния между Москвой и Вашингтоном, была проведена вторая встреча Горбачёва и Рейгана. Основной темой саммита было обсуждение проведения сокращения ядерного арсенала СССР и США. Но компромисса достигнуто не было. Рейган заявил о том, что США не прекратят разработку программы СОИ «Звёздные войны». Горбачёв же, в свою очередь, отказался обсуждать тему соблюдения прав человека. По завершению встречи оба лидера выразили своё огорчение по причине отсутствия какого-либо результата. Но М.С. Горбачёв высказал мнение, что данная встреча показала возможности и перспективы для последующих переговоров (Жуков, 1998: 211).

В 1987 году страны-участницы Варшавского договора провозгласили новую оборонительную политику организации, направленную на значительное сокращение вооружения, тем самым призывая НАТО к встречным действиям. В труде Горбачёва «Перестройка и новое мышление для нашей страны и для всего мира» им было обозначено направление советской дипломатии - отказ от конфликта социалистических и капиталистических государств и блоков, ради достижения гуманизма и всечеловеческого блага (Горбачёв, 2014: 321)

8 декабря 1987 года в Вашингтоне был подписан знаменитый Договор о ликвидации ракет средней и малой дальности, который по своей сути является первым официальным документом, в котором СССР идёт на значительные односторонние уступки - к 1991 году Советским Союзом ликвидировано 1846 ракетных комплексов, США - 846. После ДРСМД последовала целая череда отступов СССР от своих позиций: игнорирование и согласие с победами «бархатных» революций в Восточной Европе 1988-1989 гг., поддержка объединения Германии в 1990 году, подписание «Хартии для новой Европы» и последующей ликвидации ОВД и СЭВ. Таким образом, во второй половине 80 -х гг. советская внешняя политика изменилась весьма кардинально. Сложившаяся в экономике и международных отношениях ситуация активно подталкивала руководство страны активно брать кредиты и займы у МВФ, ВБ и т.д., что способствовало росту государственного долга СССР и снижения золотовалютных резервов (Громыко, 2016: 513).

Не стоит забывать, что исполнителем главной роли в происшедших событиях является руководство страны и собственно, партийные верхи. КПСС стала перерождаться ещё в 20-30-е гг., но в середине 50-х гг. этот процесс пошёл ещё быстрее. Компартия разрасталась немыслимыми темпами, хотя сам регламент приёма в члены КПСС был достаточно непростым. Каких-либо внутренних оппозиционных групп и фракций так и не появляется, а номенклатура получает всё больше и больше привилегий - от преимуществ в карьерном росте до функционирования отдельных магазинов для членов партийного ап- 
парата. Всё это привело к мощной консервации и отчуждения партии от жизни обычных трудящихся. Со всей очевидностью, данное явление проявляется уже в последние годы правления Л.И. Брежнева. И многим «коммунистам» уже становится откровенно безынтересно на положение населения и громкие марксистско-ленинские лозунги. Перерождение советской партийной элиты дошло до такой степени, что никакая идея о социализме и равенстве, да и само существование Советского Союза ей был попросту не нужны. Причём это происходило как в Москве, так и в верхушках национальных республик. Да, некоторые представители власти выступали за сохранение Союза и даже плановой экономики, они предпринимали какие-либо действия, которые не увенчались успехом (Брейтвейт, 2005: 238).

\section{Заключение}

Падение уровня жизни, дефицит товаров, проявление первых межнациональных конфликтов только подогревали дезинтеграционные настроения в союзных республиках. По абсолютно разным причинам, но в едином порыве, предпринимательские и партийные верхи и трудящиеся низы окраин стали выступать за независимость своих республик. Экономическая политика перестройки запустила вереницу деструктивных процессов: социальных, внутри- и внешнеполитических. Становится и грустно, и смешно от обвинений в адрес плановой экономики, в том, что именно она виновна в распаде СССР. Счи- таю, что Советский Союз был целенаправленно ослаблен и впоследствии разрушен методичным и безумным внедрением рынка.

В заключение хотелось бы отметить, что советское руководство могло успешно решить хотя бы часть кризисных моментов. Да, как известно, история не терпит сослагательного наклонения, но если бы ещё в 50-е годы КПСС организовала подготовку максимального числа грамотных как в практическом, так и в теоретическом плане кадров, а не осуществляла банальный набор всех в свой состав, то через 20-30 лет у власти оказались действительно идейные коммунисты. Предложенная в начале 60-х гг. общегосударственная автоматизированная система управления экономикой (ОГАС) предотвратила бюрократизацию народного хозяйства страны, что не дало бы экономических преимуществ отдельным представителям власти. Открытость политической системы и вовлечение народа в избирательные процессы также бы способствовали борьбе с усиливающейся элитарностью и отходом власти от чаяний народа. Но история сложилась так, как сложилась.

Последствия распада СССР ощущаются и спустя 30 лет, и на мой взгляд будут ощутимы ещё не одно десятилетие. Конфликт в Приднестровье, ситуация на Украине, вновь разгоревшееся противостояние в Нагорном Карабахе являются «шрамами» от события 1991 года, а попытки построения интеграционных объединений на евразийском пространстве будут неудачными без учёта ошибок прошлого.

\section{Литература}

Абалкин Л.И. (2007). Экономическая история СССР. Москва: Инфра-М. 496 с.

Брейтвейт Р. (2005). Горбачев и перестройка: парадоксы ретроспективного взгляда. 228-238 с.

Прорыв к свободе. О перестройке 20 лет спустя. Москва: Альпина Паблишер. 438 с.

Верт Н. (1992). История Советского государства. 1900-1991 гг. Москва: Прогресс. 480 с.

Гайдар Е.Т. (2020). Гибель империи. Уроки для современной России. Москва: Корпус. 592 с.

Глушаков В.А. (2019). История Китая в двадцатом веке. Москва: Энциклопедия - Ру. 480 с.

Горбачёв М.С. (2014). После Кремля. Москва: Весь мир. 416 с.

Громыко А.А. (2016). Памятное. Москва: Центрполиграф. 560 с.

Дробышевская Т.А., Мау В.А. (2011). История экономики СССР и России. Москва: Издательство Московского Университета. $272 \mathrm{c.}$

Жуков Ю.А. (1998). СССР-США: дорога длиною в семьдесят лет, или Рассказ о том, как развивались советско-американские отношения. Москва: Политиздат. 319 с.

Kissinger H. (1994). Diplomacy. New York: Simon \& Schuster, Inc. 1540 p.

Корниенко О.В. (2019). История экономики и экономической мысли СССР. Казань: Кнорус. 239 с.

Коткин С. (2018). Предотвращенный Армагеддон. Распад Советского Союза, 1970-2000. Москва: Новое литературное обозрение. $240 \mathrm{c}$.

Ратьковский И.С., Ходяков М.В. (2001). История Советской России. Санкт-Петербург: Лань. 416 с.

Рахматуллин М.А., Морозова Л.Е. (2018). История России с древнейших времен до наших дней. Москва: АСТ. 1744 с. 
Taubman W. (2018). Gorbachev: His Life and Times. New York: W. W. Norton Company. 880 p.

Хоскинг Д. (2001). История Советского Союза 1917-1991. Смоленск: Русич. 496 с.

\section{References}

Abalkin L.I. (2007). Ekonomicheskaja istorija SSSR [Economic history of the USSR]. Moskva: Infra-M. 496 s.

Braithwaite R. (2005). Gorbachev i perestrojka: paradoksy retrospektivnogo vzgljada 228-238 s. Proryv k svobode.

O perestrojke 20 let spustja. [Gorbachev and restructuring: retrospective paradoxes. 228-238 p. Breakthrough to freedom. About restructuring 20 years later]. Moskva: Al'pina Pablisher.438 s.

Vert N. (1992). Istorija Sovetskogo gosudarstva. 1900-1991 gg. [History of the Soviet state. 1900-1991 years]. Moskva: Progress. $480 \mathrm{~s}$

Gajdar E.T. (2020). Gibel' imperii. Uroki dlja sovremennoj Rossii [The fall of the empire. Lessons for today's Russia]. Moskva: Korpus.592 s.

Glushakov V.A. (2019). Istorija Kitaja v dvadcatom veke [History of China in the twentieth century]. Moskva: Jenciklopedija - Ru. $480 \mathrm{~s}$.

Gorbachev M.S. (2014). Posle Kremlja [After the Kremlin]. Moskva: Ves' mir.416 s.

Gromyko A.A. (2016). Pamjatnoe [Memories]. Moskva: Centrpoligraf.560 s.

Drobyshevskaja T.A., Mau V.A. (2011). Istorija ekonomiki SSSR i Rossii [History of the economy of the USSR and Russia]. Moskva: Izdatel'stvo Moskovskogo Universiteta.272 s.

Zhukov Ju.A. (1998). SSSR-SShA: doroga dlinoju v sem'desjat let, ili Rasskaz o tom, kak razvivalis' sovetsko-amerikanskie otnoshenija [USSR-USA: seventy-year road or a Story about how Soviet-American relations developed]. Moskva: Politizdat.319 s. Kissinger H. (1994). Diplomacy. New York: Simon \& Schuster, Inc. 1540 p.

Kornienko O.V. (2019). Istorija ekonomiki i ekonomicheskoj mysli SSSR [History of economics and economic thought of the USSR]. Kazan': Knorus.239 s.

Kotkin S. (2018). Predotvrashhennyj Armageddon. Raspad Sovetskogo Sojuza, 1970-2000 [Prevented Armageddon. The collapse of the Soviet Union, 1970-2000]. Moskva: Novoe literaturnoe obozrenie.240 s.

Rat'kovskij I.S., Hodjakov M.V. (2001). Istorija Sovetskoj Rossii [History of Soviet Russia]. Sankt-Peterburg: Lan'.416 s.

Rahmatullin M.A., Morozova L.E. (2018). Istorija Rossii s drevnejshih vremen do nashih dnej [History of Russia from ancient times to the nowadays]. Moskva: AST. $1744 \mathrm{~s}$.

Taubman W. (2018). Gorbachev: His Life and Times. New York: W. W. Norton Company.880 p.

Hosking G. Istorija Sovetskogo Sojuza 1917-1991 [History of the Soviet Union 1917-1991]. Smolensk: Rusich.496 s. 